\title{
The influence of socio-economic factors on the formation of administrative-tort and criminal policy of the government
}

\author{
S. Zakharova ${ }^{1}$. E. Nazarkin ${ }^{1}$, O. Shuranova ${ }^{1}, S$. Khamizova $^{1 *}$, E. Cherepanova ${ }^{2}$ \\ ${ }^{1}$ Academy of the Federal Penitentiary Service of Russia, st. Sennaya, 1, Ryazan, 390000, Russia \\ ${ }^{2}$ Institute of Legislation and Comparative Law under the Government of the Russian Federation, \\ Cheremushkinskaya str., 34, Moscow, 117218, Russia
}

\begin{abstract}
Poor forecasting of the results of improving administrative and criminal legislation in terms of criminalization / decriminalization of criminal acts, imperfection of the administrative-tort and criminal policy of the state leads to the assumption of unjustified criminalization of similar socially dangerous acts, the establishment of excessive administrative and criminal law prohibitions on the implementation of certain activities, as well as to incorrect decriminalization of previously established criminal law prohibitions. The study of the influence of socio-economic factors on the formation of the administrative-tort and criminal policy of the government, acting as interrelated parts of a single punitive-legal policy, is due to the need to identify the directions of its implementation, the result of which is a change in administrative and criminal legislation. The analysis of the current administrative and criminal legislation, the systematization of the theoretical provisions of the problems of criminalization / decriminalization of acts, comparison of the factors that act as their causes, made it possible to identify the grounds for the legislative changes, which include: the emergence of new types of socially dangerous human activities; unfavorable dynamics of certain types of human behavior dangerous to society, which were regulated in administrative legislation or were not considered at all as offenses; the need to strengthen the protection of constitutional rights and individual freedoms; mistakes of the earlier decriminalization of criminal acts.
\end{abstract}

\section{Introduction}

One of the priorities of the modern state is the creation of such a system of relations between the government and the person, in which everyone is given the opportunity to most fully realize their legitimate interests, protect them from encroachments, and feel protected from external and internal threats [1]. This can be achieved, first of all, through the implementation of a breakthrough scientific-technical and socio-economic development of the Russian Federation [2, 3].

*Corresponding author: a.copytowa@yandex.ru 
Various destructive phenomena, among which may be highlighted the administrativetort and criminal-legal situation, manifested in the growth of administrative offenses and criminal offenses: both in general and in individual varieties, act as an obstacle to the breakthrough development of Russia. Forecasting the development of these situations and developing proposals for improving the normative regulation of administrative-tort and criminal-legal relations, the formation of an integral system of administrative and criminal penalties are constituent elements of the state's legal policy.

The content of the state's administrative-tort and criminal policy, first of all, should meet socio-economic needs, and secondly, it should be determined by the course of the state's social development. The social, economic and political processes taking place in society that affect the state of the administrative-tort situation and crime, when quantitative indicators go into qualitative ones, as well as qualitative ones into quantitative ones, should be properly fixed in the provisions of administrative and criminal legislation which are to be applied when a specific legal situation arises.

Administrative-tort and criminal policy are integral interconnected parts of the unified punitive-legal policy of the state, which means "scientifically grounded, consistent and comprehensive activities of state and non-state structures for the further development of the system of legal punishments and legal responsibility, for improving certain types of punishment, for establishing an effective mechanism for the application of legal penalties in practice " $[4,5]$.

Improvement of administrative and criminal legislation is carried out through the criminalization / decriminalization of acts, applied when there are sufficient grounds.

Administrative and legal changes can be both law enforcement and restrictive. Law enforcement regulations are aimed at supporting the nation of the country. Law restrictive measures are applied by authorized state bodies and their officials to individuals and legal entities and other organizations in order to prevent and suppress rules and norms established by law or other regulatory legal act in various fields, including in the field of protecting human and civil rights and freedoms, protection of all forms of property, ensuring public order, compliance with sanitary and epidemiological standards. Lawrestrictive measures consist in the introduction of new compositions of administrative offenses or the toughening of the sanctions of already existing norms in the Code of Administrative Offenses of the Russian Federation.

Failure to achieve the goals of punitive legal policy by administrative legal means requires influencing the current situation by using criminal legal means. In this connection, the application of the institution of administrative prejudice in criminal law is expanding.

The purpose of the study is to establish the grounds for the criminalization / decriminalization of socially dangerous acts; determination of the legal content and signs of administrative prejudice in criminal law. Achievement of this goal will make it possible to formulate proposals for improving the Russian criminal law, to determine the factors that serve as grounds for the criminalization / decriminalization of acts. To achieve this goal, it is necessary to solve the following tasks:

- to analyze the norms of administrative and criminal legislation regulating similar dangerous acts in order to establish the grounds for the transition from administrative to criminal legal means of regulating them;

- consider the grounds for the criminalization / decriminalization of acts;

- to analyze the corpus delicti with administrative prejudice, embodied in the Criminal Code of the Russian Federation;

- to study the statistical data of the Judicial Department at the Supreme Court of the Russian Federation on the considered cases of administrative offenses and criminal cases of crimes with administrative prejudice on the expediency of establishing criminal law bans for repeated committing of administrative offenses. 


\section{Review of literature on the topic of research and research methodology}

The problems of improving administrative and criminal legislation through the criminalization / decriminalization of socially dangerous acts, the grounds for their implementation, the use of the institution of administrative prejudice in criminal law have been the subject of numerous scientific studies. So, L.M. Prozumentov studied the grounds for the criminalization / decriminalization of acts [6]. The issues of theoretical justification for the use of administrative prejudice in Russian criminal law at the level of dissertation research were studied by A.V. Bogdanov (Moscow, 2019) [7], Z.E. Ergasheva (Moscow, 2019) [8]. In the Russian science of criminal law, there are also other studies of different years on the stated problems, but, despite this, the problem of interdependent improvement of administrative and criminal legislation within the framework of the implementation of the government's administrative-tort and criminal policy remains not fully resolved.

The research methodology is built on the basis of an analysis of the current administrative and criminal legislation, theoretical provisions on the problems of criminalization / decriminalization of acts and the identification of factors that act as their causes, the definition of the institution of administrative prejudice and its features, their systematization, comparison, and the formulation of intermediate and final conclusions. The tools used made it possible to formulate the definition of administrative prejudice in criminal law, highlight its features, make proposals for improving the legislation regulating criminal liability for various types of fraud, and securing the introduction of the institution of administrative legal regulation of certain types of crimes.

\section{Results}

The study showed that poor forecasting of the results of improving administrative and criminal legislation in terms of criminalization / decriminalization of unlawful / criminal acts, imperfection of the administrative tort and criminal policy of the state leads to the assumption of unjustified criminalization of similar socially dangerous acts in administrative and criminal legislation, unjustified expansion of the list of compositions crimes with administrative prejudice, as well as erroneous decriminalization, entailing the subsequent re-criminalization of a socially dangerous act. Based on the results of the study, a proposal was made to improve the criminal legislation, in terms of consolidating the concept and content of "administrative prejudice" in criminal law, clarifying the signs and grounds for its application.

\section{Discussion}

E.V. Dodin, considering the administrative-tort policy, defines it as "a part of national policy, which is the activity of the state and society to develop and implement measures aimed at combating administrative offenses and their prevention" [9].

VC. Kolpakov considers this category as "purposeful prognostic activity of the state to determine and theoretically substantiate the needs for the introduction and lifting of bans on the actions of physical and collective subjects; establishing and adjusting administrative liability for their violation; as well as the formation, functioning and scientific support of administrative and tort legislation in accordance with the state legal policy" [10].

It is necessary to consider the administrative-tort policy in relation to the criminal policy of the government. The latter is defined as "the system of officially adopted in the state regulations that determine the essence, purpose and criteria of rule-making and law 
enforcement in the field of protecting the individual, society and the nation from criminal encroachments by criminal means" $[11,12]$. The result of the criminal policy pursued in the government is the change in criminal legislation, in particular, the criminalization or decriminalization of certain types of criminal encroachments.

Criminalization is understood as the process of "identifying acts dangerous for the individual, society and the nation and recognizing them as criminal by establishing a ban on their commission in the criminal law" [13].

L.M. Prozumentov, considering the grounds for criminalization, noted that "the specific grounds for criminalization that determine its necessity are:

1. The emergence of a socially dangerous act with a sufficiently high degree of social danger (which may be due to the emergence of new relations - the object of encroachment).

2. An increase in the degree of public danger of an act (a consequence of an increase in the degree of public danger of a method of committing an offense or as a result of a change in the social significance of harm from this offense)[6]. In our opinion, this position is not complete. The list of grounds for the criminalization of acts should be expanded and one more basis should be supplemented - the identification of an error in the earlier decriminalization of criminal acts.

Considering the criminalization of N.A. Lopashenko, identifies the following factors that act as its reasons (grounds): 1) the emergence of new types of socially dangerous human activities; 2) unfavorable dynamics of certain types of human behavior dangerous for society, which were regulated in administrative legislation or were not considered at all as offenses; 3) the need to strengthen the protection of constitutional rights and individual freedoms; 4) errors of the earlier decriminalization of criminal acts [14]. We agree with the opinion of N.A. Lopashenko.

For example, the situation that has developed in connection with the threat of the spread of a new coronavirus infection has made it necessary to improve the current legislation. In this regard, in an expedited manner, were considered, adopted and put into effect the following Federal Laws of April 1, 2020 No. 98-FL «On Amending Certain Legislative Acts of the Russian Federation on the Prevention and Elimination of Emergencies" and 99FL "On Amending the Code of Administrative Offenses of the Russian Federation».

The Code of Administrative Offenses of the Russian Federation introduced norms related to the observance of the non-contact regime between citizens, as well as aimed at protecting citizens from material losses caused by measures to combat the new infection COVID-19, which, by the Decree of the Government of the Russian Federation of January 31, 2020 No. No. 66 is included in the List of Diseases dangerous to persons in the vicinity. The sanction of Article 6.3 was changed. Administrative Code ("Violation of legislation in the field of ensuring the sanitary and epidemiological well-being of the population"). Responsibility for this offense was significantly increased (the amount of the fine was increased, if earlier it ranged from 100 to 500 rubles, then during the pandemic the size of the fine was from 15,000 to 40,000 rubles).

The establishment of criminal law prohibitions on the commission of socially dangerous acts should be applied only in cases where other types of responsibility (including administrative and legal) have exhausted their preventive potential and socially dangerous behavior requires exposure precisely through the use of criminal law means [11 ]. Recently, in the Criminal Code of the Russian Federation, one can observe cases when the legislator uses prejudicial criminalization, which provides for the introduction of a criminal law prohibition on the basis that a person was previously brought to administrative responsibility and an administrative penalty was imposed on him for the committed act provided for by the Code of the Russian Federation on Administrative offenses.

With the adoption of the Criminal Code of the Russian Federation in 1996, the legislator completely abandoned the institution of "administrative prejudice" in criminal law, 
justifying this by the contradiction of the administrative prejudice to the constitutional principle of the impossibility of re-conviction for the same crime (Article 50 of the Constitution of the Russian Federation).

But already in 2009, the institution of administrative prejudice was returned to the criminal legislation. The reason for the resumption of the application of this legal institution was the Address of the President of the Russian Federation to the Federal Assembly of the Russian Federation (2009), in which it was noted that "in the criminal law, the so-called administrative prejudice should be used more widely, that is, brought to criminal responsibility only in the case of repeated committing an administrative offense " [15].

The further development of the institute was defined in the Strategy of the State AntiDrug Policy of the Russian Federation until 2020 No. 690 [16]. In 2011, the Academy of the Prosecutor General's Office of the Russian Federation held a meeting on the admissibility of administrative prejudice in the criminal law of Russia [17].

As of 2020, it is noted that the institution of administrative prejudice is undergoing a "reanimation process", and there is a tendency to an increase in the number of corpus delicti with administrative prejudice. If in 2009 one corpus delicti was introduced with an administrative prejudice, then at the beginning of 2020 twelve such corpus delicti were introduced into the Criminal Code of the Russian Federation (look at the diagram 1).

In a general sense, prejudice should be understood as the obligation in procedural law for all courts that consider a case to accept, without verification and evidence, the facts previously established by a court decision that entered into legal force or a judgment in another case [18].

Prejudice is normatively fixed in the Criminal Procedure Code of the Russian Federation. In accordance with Art. 90 of the Code of Criminal Procedure of the Russian Federation, circumstances that have been established by a verdict that have entered into legal force, or by another court decision that has entered into legal force, adopted within the framework of civil, arbitration or administrative proceedings, are recognized by the court, prosecutor, investigator, interrogator without additional verification, if these circumstances are beyond doubt at the court. Moreover, such a verdict cannot prejudge the guilt of persons who have not previously participated in the criminal case under consideration [19].

Now let us turn our attention to the administrative prejudice in criminal proceedings, that is, the circumstances established by a court decision that has entered into legal force, adopted within the framework of administrative proceedings on the fact that a person has committed an administrative offense for which an administrative penalty has been assigned to him.

In Russian criminal law, there are different points of view regarding the concept and content of administrative prejudice. In its most general form, this legal institution can be defined as bringing a person to criminal liability if, within a certain period of time after one or two administrative punishments for a wrongful act, he commits a similar act [20].

The essence of the institution of administrative prejudice, according to V.L. Zueva, "lies in the fact that the corpus delicti is formed due to signs of an administrative offense, and the fact of the previous imposition of an administrative penalty for the same act acts as a criterion for distinguishing between crime and misconduct" [21].

Taking into account the analysis of the definitions of the category "administrative prejudice", in our opinion, it should be understood as a legal phenomenon that reflects the so-called transformation (transition) of legal responsibility from the administrative plane to the criminal one, which is due to the connection of the subsequent committed administrative act with administrative punishment for the previous similar act [18].

It is necessary to highlight a number of features that characterize the legal content of the administrative precedence. In particular, these include:

1) a quantitative feature (repetition) - a repetition of the commission of similar 
administrative offenses (two or more), for which the subject has already been brought to administrative responsibility and who was assigned an administrative penalty.

So, for example, Art. 116 of the Criminal Code of the Russian Federation provides for criminal liability for beating by a person subjected to administrative punishment, and stipulates that beating or committing other violent actions by a person subjected to administrative punishment for a similar act that caused physical pain, but did not entail a short-term disorder of health or insignificant persistence loss of general working capacity, and not containing signs of corpus delicti under Art. 116 of the Criminal Code of the Russian Federation, entail criminal prosecution. That is, the repeated commission of similar administrative acts, entailing the appointment of an administrative penalty, indicates the emergence of grounds for bringing to criminal liability;

2) the presence of a certain time interval when the acts were committed. For example, in note 1 to art. 157 of the Criminal Code of the Russian Federation stipulates that the act provided for in Part 1 of Art. 157 of the Criminal Code of the Russian Federation is recognized as committed repeatedly if a person is again subjected to administrative punishment for a similar act, during the period when the person is considered to be subject to administrative punishment.

In accordance with the Art. 4.6 of the Code of Administrative Offenses of the Russian Federation, the period during which a person is considered to be subject to an administrative penalty is regulated as follows: «A person who has been assigned an administrative penalty for committing an administrative offense is considered to be subject to this punishment from the date of entry into force of the decision on the imposition of an administrative penalty until the expiration of one year from the date of completion of the execution of this decision» $[22]$.

3) the presence of a deliberate form of guilt in the commission of an initial administrative offense and a subsequent similar act, etc.

So, in 2011, the Criminal Code of the Russian Federation included a criminal legal norm that establishes responsibility for the retail sale of alcoholic products to minors, committed repeatedly (Article 151 of the Criminal Code of the Russian Federation).

According to the footnote to this article, retail sale of alcoholic products to a minor committed by a person repeatedly is considered to be retail sale of alcoholic products to a minor by a person subjected to administrative punishment for a similar act, during the period when the person is considered to be subject to administrative punishment.

Thus, studying the subjective side of the said crime, it should be noted that it consists in the deliberate commission of the above actions during the period when a person is considered to be subjected to administrative punishment for a similar action. That is, a person subject to administrative punishment is aware of the social danger of the act he is committing and wants to commit it.

In the period from 2014 to 2018 , several more norms with administrative prejudice were included in the Criminal Code of the Russian Federation: Art. 212 of the Criminal Code of the Russian Federation - repeated violation of the established procedure for organizing or holding a meeting, meeting, demonstration, march or picketing. This rule is applicable if a person has already been brought to administrative responsibility more than twice within 180 days for committing administrative offenses provided for in Article 20.2 of the Code of Administrative Offenses of the Russian Federation; Art. 264 of the Criminal Code of the Russian Federation - violation of traffic rules by a person who has already been subjected to administrative punishment; Art. 2841 of the Criminal Code of the Russian Federation carrying out activities on the territory of the Russian Federation by a foreign or international non-governmental organization which activities recognized as undesirable on the territory of the Russian Federation; part 2 Art. 314 of the Criminal Code of the Russian Federation. In this legal norm, repeated non-compliance by a person with respect to whom 
administrative supervision has been established, administrative restrictions or restrictions imposed on him by a court in accordance with federal law, recognizes non-compliance by a person in respect of whom administrative supervision has been established, administrative restrictions or restrictions established by the court in accordance with with federal law, provided that this person was previously brought to administrative responsibility for a similar act two times within one year; Art. 215 of the Criminal Code of the Russian Federation - providing for criminal liability for illegal entry into a protected object; Art. 116 of the Criminal Code of the Russian Federation - beating by a person subject to administrative punishment; Art. 157 of the Criminal Code of the Russian Federation - nonpayment of funds for the maintenance of children or disabled parents; Art. 158 of the Criminal Code of the Russian Federation - petty theft committed by a person subject to administrative punishment; Art. 171 of the Criminal Code of the Russian Federation illegal retail sale of alcoholic and alcohol-containing food products; part 1 Art. 282 of the Criminal Code of the Russian Federation - incitement to hatred or enmity, as well as humiliation of human dignity.

Despite the return of the institution of administrative prejudice to criminal law, individual legislative provisions remain heterogeneous. In some articles, the legislator connects the possibility of bringing to criminal responsibility for committing administrative offenses with bringing to administrative responsibility for similar acts within one year (part 1 of article 282 of the Criminal Code of the Russian Federation), in others - with the use of administrative punishment (article 158 of the Criminal Code of the Russian Federation ); in the third - with the commission of the act repeatedly, that is, the commission by a person subjected to administrative punishment for a similar act, during the period when the person is considered to be subject to administrative punishment (Article 171 of the Criminal Code of the Russian Federation).

The active use of administrative prejudice in the design of corpus delicti can be mostly explained by the possible prevention and suppression of administrative offenses and crimes in the future.

But we cannot but agree with the opinion of E.A. Gerasimova that "administrative law is not designed to counter crime" [23]. Also N.A. Lopashenko draws attention to the fact that administrative prejudice is nothing more than "shifting responsibility for the lack of prevention of offenses from the perpetrators of this to the offender who committed the offense " [24].

Despite the fact that criminal structures with administrative prejudice, although they are enshrined in the Criminal Code of the Russian Federation, they continue to be administrative offenses that are committed more than 2 times by the same person within the time frame established by law.

We propose to introduce Article 16 [1] "Administrative Prejudice" in the General Part of the Criminal Code of the Russian Federation as follows:

"An administrative prejudice is the commission of an intentional crime by a person who has been subjected to administrative punishment for a similar or same act during the period when the person is considered to be subjected to administrative punishment."

Considering the errors of the earlier decriminalization of criminal acts as a basis for criminalization, we note that this basis becomes possible in the case when the forecast of the development of a criminal situation was incorrectly carried out. So, in 2011, Article 129 of the Criminal Code of the Russian Federation, which provides for criminal liability for libel, was declared invalid, and therefore the possibility of criminal prosecution for this act was excluded. However, in 2012, Article 128 of the Criminal Code of the Russian Federation was introduced, which revived criminal liability for libel. All this testifies to the need for a thorough analysis of the current criminal situation and long-term forecasting of its development. 
Along with criminalization, another form of implementation of the government's administrative-tort and criminal policy is decriminalization, that is, the reverse process of criminalization.

The grounds for decriminalization can be:

1. Loss of an act of that degree of social danger that required the application of measures of a criminal-legal nature, including punishment, for its commission, as a result of changes that have occurred in the economic, political, social and other spheres of society.

2. The disappearance of the public danger of the act due to the disappearance of a certain type of social relations, which were protected by the criminal law (the object of criminal encroachment).

As with the criminalization of acts, the decriminalization process must be justified and predictable. Unjustified decriminalization, as we have previously demonstrated, entails recriminalization of socially dangerous acts.

\section{Conclusion}

Administrative-punitive and criminal policy are parts of the unified punitive-legal policy of the state, aimed at improving the mechanism of legal regulation of public relations in need of state protection. The main ways of implementing the tasks of administrativepunitive and criminal policy are the criminalization / decriminalization of acts.

The following grounds for criminalization should be highlighted:

1. The emergence of a socially dangerous act with a sufficiently high degree of social danger (which may be due to the emergence of new relations - the object of encroachment).

2. An increase in the degree of public danger of an act provided for in administrative legislation (a consequence of an increase in the degree of public danger of a method of committing an offense or due to a change in the social significance of harm from this offense). " This basis applies if the administrative and legal responsibility has exhausted its preventive potential and socially dangerous behavior requires exposure precisely through the use of criminal law means.

3. Revealing the error of the previously carried out decriminalization of a criminal act, entailing its re-criminalization. Mistakes in decriminalization become possible in the absence of long-term forecasting of a criminal situation.

The transition from administrative-tort to criminal regulation of issues of responsibility for the commission of socially dangerous acts is associated with the use of the institution of administrative prejudice in criminal law.

Expansion of the application of this institution requires legislative consolidation of the category "administrative prejudice" in the Criminal Code of the Russian Federation.

It is advisable to introduce article 16 "Administrative prejudice" in the General Part of the Criminal Code of the Russian Federation with the following content:

«An administrative prejudice is the commission of an intentional crime by a person who has been subjected to administrative punishment for a similar or same act during the period when the person is considered to be subjected to administrative punishment.»

As a reverse process of criminalization, decriminalization is carried out in the presence of the following grounds:

1. Loss of an act of that degree of social danger that required the application of measures of a criminal-legal nature, including punishment, for its commission, as a result of changes that have occurred in the economic, political, social and other spheres of society.

2. The disappearance of the public danger of the act due to the disappearance of a certain type of social relations, which were protected by the criminal law (the object of criminal encroachment). 
As with the criminalization of acts, the decriminalization process must be justified and predictable. Unjustified decriminalization, as we have previously demonstrated, entails recriminalization of socially dangerous acts.

\section{References}

1. Tsyndrya V.N. To the definition of the concept of "administrative punishment policy" // Scientific notes of the Crimean Federal University named after V.I. Vernadsky. Legal sciences. 2018.Vol. 4 (70). No. 4. P. 277-283.

2. On national goals and strategic objectives of the development of the Russian Federation for the period up to 2024: Decree of the President of the Russian Federation of May 7, 2018 No. 204 // SPS "ConsultanPlus".

3. On the national development goals of the Russian Federation for the period up to 2030: Decree of the President of the Russian Federation dated July 21, 2020 No. 474 // SPS "ConsultanPlus".

4. Malko A.V., Nyrkov V.V., Rodionova A.S. The system of legal punishments: a general theoretical approach to the formation of a concept // Punishment and responsibility in Russian law / ed. A.V. Malko. M., 2014. P. 36.

5. Rodionova A.S. The system of punishments in Russian law (general theoretical aspect): dis. ... Cand. jurid. Sciences: 12.00.01 / A.S. Rodionova. Saratov, 2013. P. 137.

6. Prozumentov L.M. The basis for the criminalization (decriminalization) of acts // Bulletin of the Tomsk State University. Right. 2014. No. 4 (14). P. 81-91.

7. Bogdanov A.V. Administrative prejudice in the criminal law of Russia: dis. ... Cand. jurid. Sciences 12.00.08 / A.V. Bogdanov. M., 2019.251 p.

8. Ergasheva Z.E. Administrative prejudice in criminal law: dis.... Cand. jurid. Sciences 12.00.08 / Z.E. Ergashev. M., 2019.215 p.

9. Dodin E.V. The concept and reasons for administrative delinquency // problems of administrative law and the improvement of administrative activities of internal affairs bodies. Sat. scientific. works / otv. ed. V.A. Demidenko. Kiev, 1981.P. 49.

10. Kolpakov V.K. A delicate phenomenon in the administrative law of Ukraine: author. dis. ... Dr. jurid. Sciences: 12.00.07 / V.K. Kolpakov. Kiev, 2005.39 p.

11. Bryka I.I., Khaperskaya K.S. Criminal law policy and criminalization / decriminalization of criminal law // Legal Concept = Legal paradigm. 2019.Vol. 18.No. 2. P. 153-158.

12. Kondrat I.N. Concept of criminal policy and improvement of criminal and criminal procedure legislation / I.N. Kondrat // Bulletin of MGIMO. 2013. No. 3 (30). P. 105-109.

13. Korobeyev A.I. Complete course of criminal law: in 5 volumes. V. 1. Crime and Punishment / A.I. Korobeev. SPb .: Press, 2008 . 1133 p.

14. Russian criminal law. General and Special parts: textbook. in 3 volumes / ed. ON. Lopashenko. 2nd ed., Rev. and add. T. 1: General part. M., 2014 P. 51.

15. Message of the President of the Russian Federation to the Federal Assembly of the Russian Federation in 2009 [Electronic resource] // SPS "ConsultantPlus".

16. Strategy of the state anti-drug policy of the Russian Federation until 2020, approved. By the Decree of the President of the Russian Federation of 09.06.2009 No. 690. Rossiyskaya Gazeta 15.06.2010

17. Tripoleva AI Administrative prejudice: pros and cons // Young scientist. 2019. No. 16. S. $125-128$.

18. Zakharova S.S., Oreshkova D.O. Features of criminal liability in the presence of an administrative prejudice // In collection: STUDENT OF THE YEAR 2019. Collection of articles. articles of the International Research Competition: at 3 pm 2019, p. 10-16. 
19. Gavrikov VP Theory of state and law: textbook and workshop for secondary vocational education / VP Gavrikov. Moscow: Yurayt Publishing House, 2019, 454 p. - P. 297.

20. Kolosova V.I. Administrative prejudice as a means of preventing crimes and improving criminal legislation. // Bulletin of the Nizhny Novgorod University. N.I. Lobachevsky. 2011. No. 5 (1). P. 248.

21. Zuev V.L. Features of proof in cases of crimes with administrative precedence. M .: UMC at the Main Directorate of the Ministry of Internal Affairs of Russia, 1995. P. 3.

22. G. Kozlov, M. Pushkarev, E3S Web of Conferences, 135, 01058 (2019) doi: 10.1051/e3sconf/201913501058

23. Gerasimova E.A. Criminal and legal opposition to retail sale of alcoholic beverages to minors: dis. ... Cand. jurid. sciences. Saratov, 2015. P. 119.

24. Lopashenko N.A. Administrative prejudice in criminal law - no! // Bulletin of the Academy of the General Prosecutor's Office of the Russian Federation. 2011. No. 3 P. 69. 